\title{
Properties of fly ash and slag from the power plants
}

\author{
Miloš Šešlija ${ }^{1}$, Aleksandra Rosić ${ }^{2}$, Nebojša Radović ${ }^{1}$, Milinko Vasić ${ }^{1}$, Mitar Đogo ${ }^{1}$ and Milovan Jotić ${ }^{3}$ \\ ${ }^{1}$ University of Novi Sad, Faculty of Technical Sciences, Department of Civil Engineering and Geodesy, Trg Dositeja Obradovića 6, 21000 Novi Sad, Republic of Serbia; \\ (slavijasrb@gmail.com) \\ 2 University of Belgrade, Faculty of Mining and Geology, Đušina 7, 11000 Belgrade, Republic of Serbia \\ ${ }^{3}$ Highway Institute A.D., Kumodraška 257, 11000 Belgrade, Republic of Serbia
}

doi: $10.4154 / g c .2016 .26$

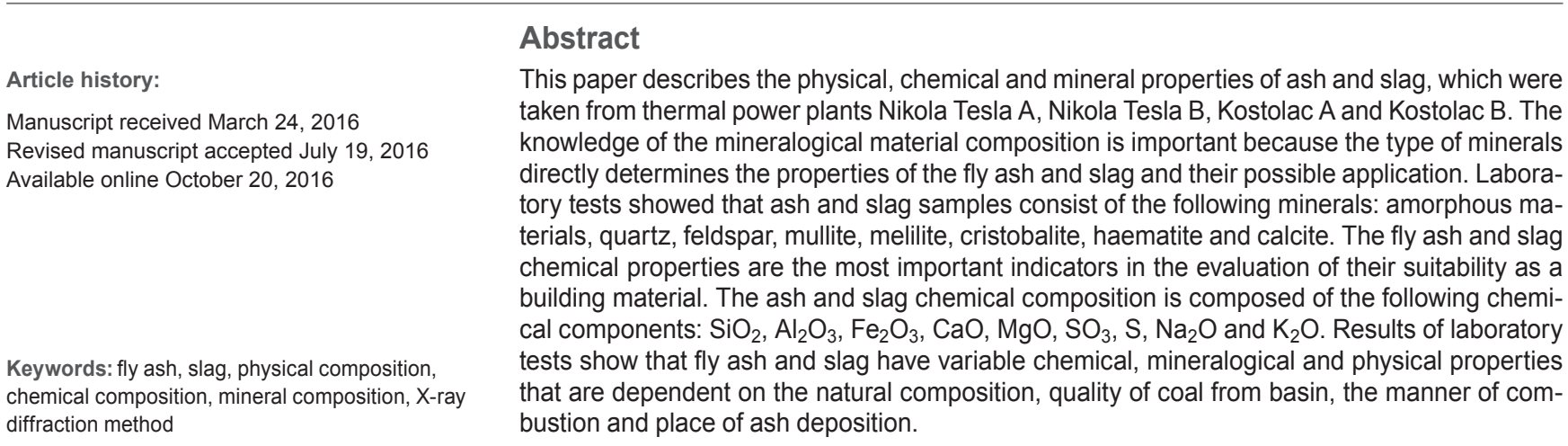

\section{INTRODUCTION}

Fly ash is the product of burning coal and arises from inorganic substances melting in the thermal power plants. The fly ash particles have a spherical shape, dimensions of $0.074-0.005 \mathrm{~mm}$, are of low density, very mobile and can cause a number of problems in the environment. Slag is a mineral mixture that consists of material melted in the combustion process and other parts of noncombustible material. It falls through the latticed stokehole and is rapidly cooled and extinguished in water. The fly ash and slag landfills in Serbia occupy an area of 1639 ha and if they are under constant control and monitoring, significantly influence the disruption of the environment, which is reflected in the pollution of: air, soil, surface water and groundwater, vegetation cover, as well as in the steady ecosystems disruption that affects human health (MILETIĆ \& ILIĆ, 2007).

All the negative environmental indicators caused by fly ash and slag can be eliminated or reduced if they are used as building material for road construction and other trafficked areas. The using of fly ash and slag as secondary materials for road constructions, saves huge amounts of standard building materials (stone, gravel, sand), which are non-renewable. Most of the research is based on an examination of the chemical composition of the ash (THOMAS, 2007; KIM et al., 2005), the mineral ash composition (ŽIVOTIĆ et al., 2015), the mineral ash and coal composition (WARD \& FRENCH, 2005) and chemical-mineral ash composition (VASSILEV et al., 2013; VASSILEV et al., 2014; VASSILEV et al., 2003; VASSILEV et al., 2004a; VASSILEV et al., 2004b; VASSILEV \& MENENDEZ, 2005). There are many papers of narrower scope that establish correlations between the chemical, mineral and physical properties of fly ash (VASSILEV \& VASSILEVA, 2007). Based on the most common characteristics (chemical and mineral composition) of ash and slag from the Kolubara and Kostolac coal basins, the research objectives presented in this paper are the laboratory testing and research of the physi- cal properties, chemical and mineral compositions of the fly ash from thermal power plants (PP) ,Nikola Tesla A” (NT A), „Nikola Tesla B” (NT B), „Kostolac „A” (KO A) and „Kostolac B” (KO $\mathrm{B})$. The physical properties of the ash and slag facilitate their use as building materials for transport infrastructure, reducing the use of natural resources inroad building projects. The chemical properties of fly ash and slag are the most important indicator in the evaluation of their suitability as a building material. Knowledge of the material mineralogical composition is significant because the type of minerals directly determines the properties of fly ash and slag and their applications. The aim of this paper is based on establishing a correlation between the physical properties, chemical and mineral composition of the ash and slag. Established correlations are indicators for defining the origin, properties, as well as the possibility of fly ash and slag application as a construction substitute thus preservinglimited reserves of natural building materials.

\section{STUDY AREA}

PPNT A is the most important producer of electricity in Serbia and is built on the bank of the river Sava. PPNT A is $4 \mathrm{~km}$ from Obrenovac, PPNT B is located $16 \mathrm{~km}$ upstream from PPNT A (Fig. 1). Both PPNT use coal from the Kolubara basin.

The Kolubara lignite basin is economically one of the most important coal basins in Serbia. It is located about $60 \mathrm{~km} \mathrm{SSW} \mathrm{of}$ Belgrade, and covers an area of almost $600 \mathrm{~km}^{2}$, extending in an $\mathrm{E}-\mathrm{W}$ direction for up to $55 \mathrm{~km}$, and in the N-S direction up to $15 \mathrm{~km}$. This basin is divided into several fields („A”, „B”, „C”, „D”, „E”, „F”, „G”, „Veliki Crljeni”, „Šopić-Lazarevac”, „Tamnava Istok”, „Tamnava Zapad”, ,Radljevo”, ,Zvizdar” and „Ruklade”; Fig. 2). Lignite is exploited in fields „C”, „D” and „Tamnava Zapad". The D field which is the focus of this study is situated in the eastern part of the Kolubara basin. When exploitation began it extended over an area of almost $20 \mathrm{~km}^{2}$, now the 


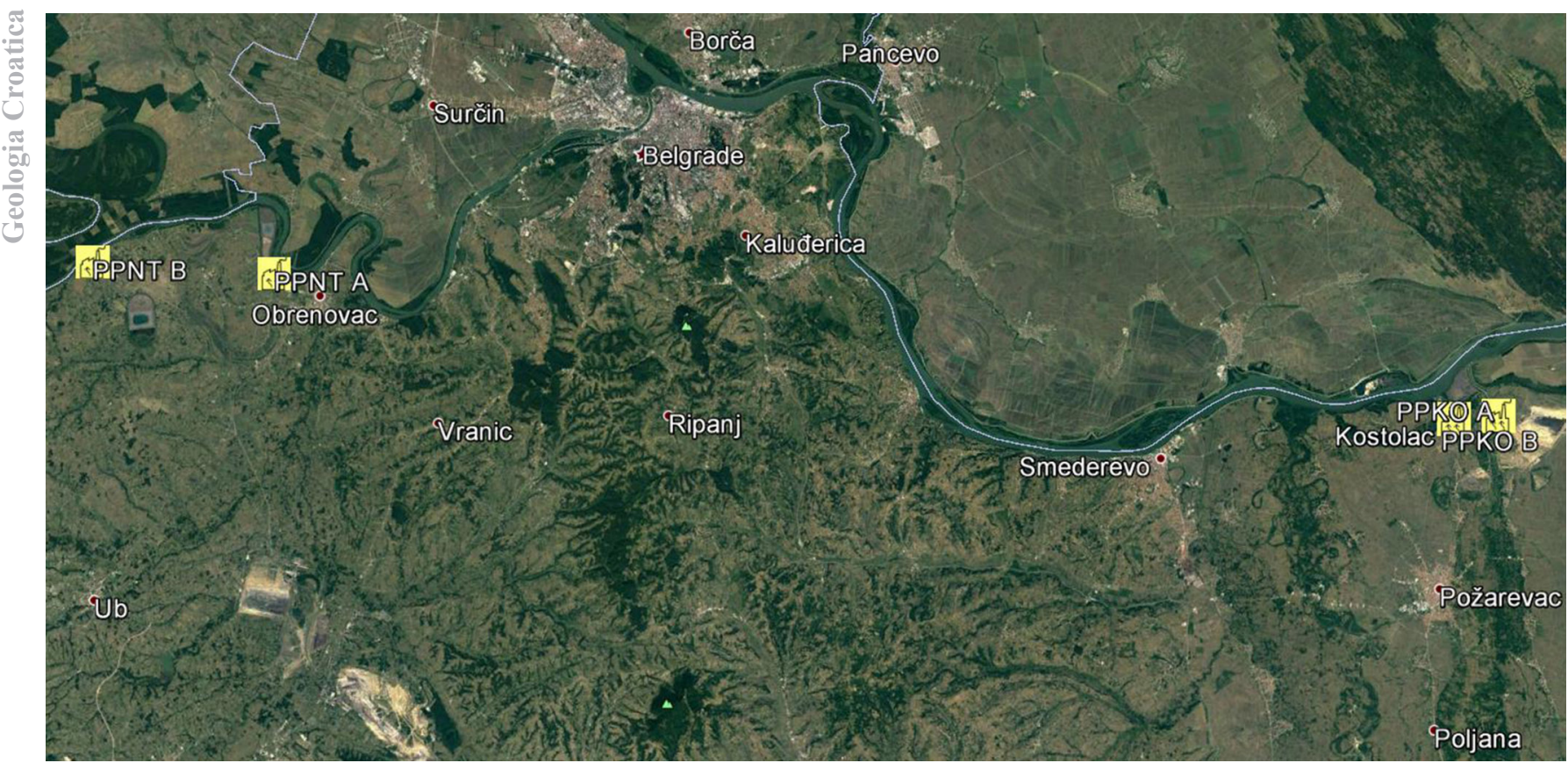

Figure 1. Map of the study area (www.maps.google.com).

remaining surface with mineable coal seams is about $6 \mathrm{~km}^{2}$. The northern border is represented by outcropping and erosion of the Main coal seam. The western border of the deposit is a natural extension to the $\mathrm{G}$ field and the southern boundary to the E field. The eastern border is also marked by outcropping of the Main coal seam (ŽIVOTIĆ et al., 2013).

Since 1896, about 883.2Mt of lignite in total, has been produced from the Kolubara basin, of which $866.8 \mathrm{Mt}$ was form open pit mines and 16.3Mt from underground mines (active until 1974). Annually, the Kolubara basin produces about 30Mt lignite, which amounts to $70 \%$ of the total coal production in Serbia. According to the Geological Survey of the Kolubara basin, the lignite resources and reserves are currently estimated at 2811Mt. Most of the lignite produced $(90 \%)$ is used for electricity generation in thermal power plants „Nikola Tesla A” (NT A) and „Nikola Tesla B" (NT B). About 17 billion $\mathrm{kWh}$ is produced annually from Kolubara coal, which represents $52 \%$ of Serbia's total electricity generation (ŽIVOTIĆ et al., 2013).

In the Kostolac coal basin two thermal power plants were built. PPKO A is located on the right bank of the river Danube,

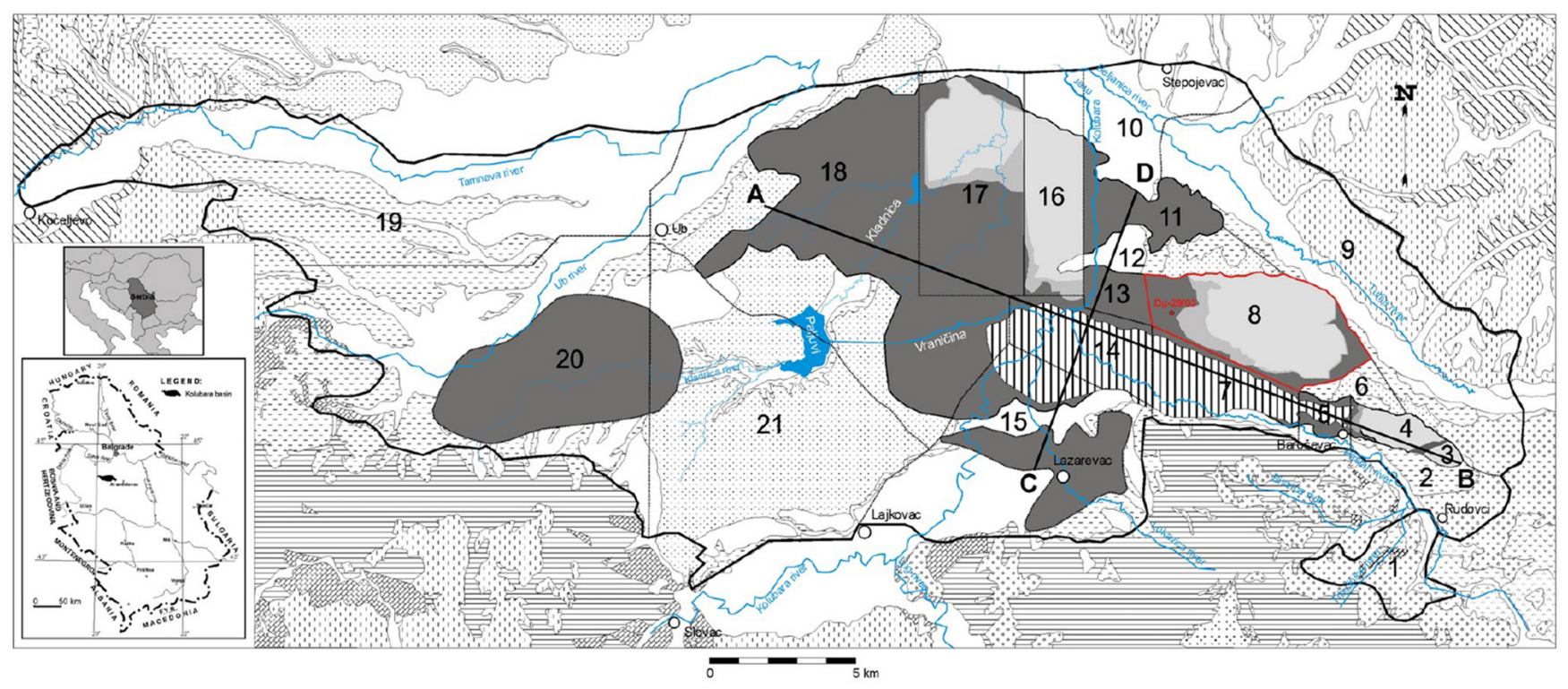

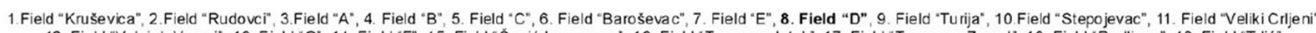
12. Field "Volujak-Vreod', 13. Field 'G', 14. Field 'F", 15. Field 'Sopić-Lazarevac', 16. Field 'Tamnava-Istok', 17. Field "Tamnava-Zapad', 18. Field 'Radljevo", 19. Field "Trlic',

\begin{tabular}{|c|c|c|c|c|}
\hline \multicolumn{5}{|l|}{ Legend: } \\
\hline $\begin{array}{l}\text { Kolubara coal basin (area around } 600 \mathrm{~km}^{2} \text {, sterile-barren zones), } \\
\text { thin coal layers as eqivalents to the main coal seam }\end{array}$ & $\begin{array}{l}\text { Dg-29/03 Studied borehole } \\
\text { A B Cross-sections }\end{array}$ & $\begin{array}{l}\text { Upper Miocne: Upper Pontian, } \\
\text { sand, silt, grave, coal, clay }\end{array}$ & 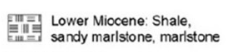 & 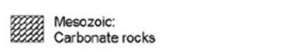 \\
\hline $\begin{array}{l}\text { Main coal seam, explored resserves and } \\
\text { resources in area of } 167 \mathrm{~km}^{2}\end{array}$ & & $\begin{array}{l}\text { Upper Miocene: Pannonian } \\
\text { sand, clay, gravel, marlstone }\end{array}$ & Lower Miocene: & $\begin{array}{l}\text { Paleozoc: Phylite, sericite-chiorite } \\
\text { schist, sandstone, limestone and shale }\end{array}$ \\
\hline $\begin{array}{l}\|\|\|\| \| \text { Upper coal seam, explored reserves and } \\
\text { resources in area of } 30 \mathrm{~km}^{2}\end{array}$ & $\begin{array}{l}\text { Quaternary: } \\
\text { alluvial sand and gravel }\end{array}$ & $\begin{array}{l}\text { AY Middle Mocene: Sarmatian } \\
\text { Limestone, send clay, marlstone }\end{array}$ & $\begin{array}{l}\text { Oligocene: } \\
\text { Granodiorte }\end{array}$ & Studied area \\
\hline $\begin{array}{l}\text { Main coal seam, excavated } \\
\text { reserves as of } 31.12 .2009 \text {. }\end{array}$ & $\begin{array}{l}\text { Quaternary } \\
\text { clayey-sendy sediments }\end{array}$ & $\therefore$ Middle Mocene: Badenian, & $\begin{array}{l}\text { Mesozoic: Upper Cretaceous } \\
\text { Flysch }\end{array}$ & \\
\hline
\end{tabular}

Figure 2. Geological map of the Kolubara basin (from ŽIVOTIĆ et al., 2013). 


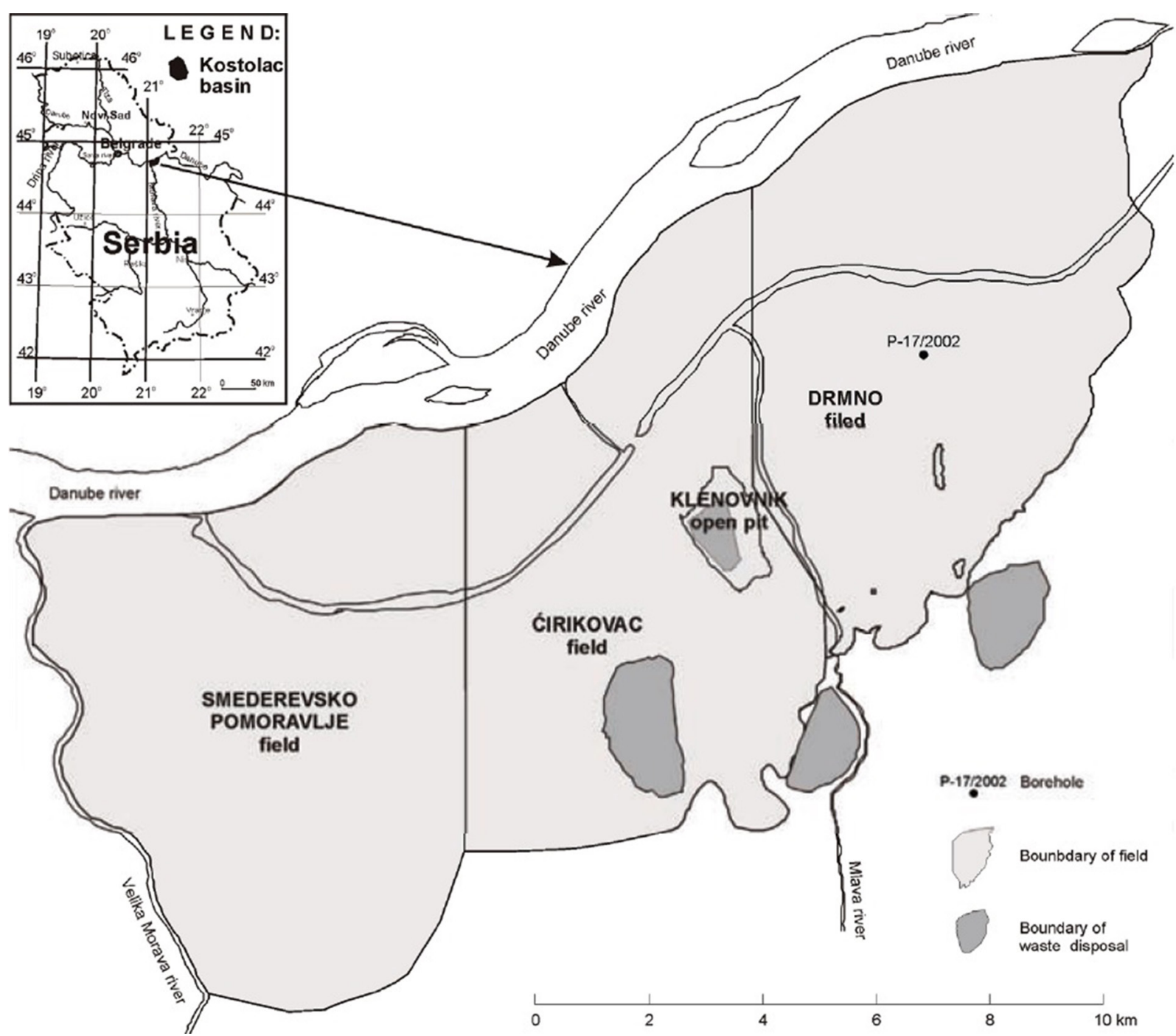

Figure 3. Location and coal fields of the Kostolac basin (STOJANOVIĆ et al., 2012).

on the edge of place Kostolac, while PPKO B is located on the northeastern part of the Kostolac coal basin near the village of Drmno (Fig. 1).

The Kostolac coal basin, covering an area of $145 \mathrm{~km}^{2}$, is located about $90 \mathrm{~km}$ east of Belgrade. It is divided into three coal fields: the Drmno field in the eastern, the Ćirikovac field in the central and the Smederevsko Podunavlje field in the western parts of the basin (Fig. 3). The Drmno and Cirikovac fields are exploited, while the Smederevsko Podunavlje field is still under preliminary exploration (STOJANOVIĆ et al., 2012).

\section{GEOLOGY}

The area of the Kolubara basin consists of Palaeozoic, Mesozoic, Tertiary and Quaternary rocks (Fig. 4) (ŽIVOTIĆ et al., 2015). The basement of this basin consists of Devonian and Carboniferous schists, gneisses, slates and sandstones, Mesozoic mica-rich sandstones, shales, dolomitic limestones, limestones and flysch (alternation of limestones, marlstones, sandstones and siltstones), and Tertiary phenoandesites, phenodacites, quartz-latite, ignimbrites and quartz-latite tuffs. The Pontian (Upper Miocene) fresh water clastic sediments host three coal seams (KEZOVIĆ, 2011): Seam III or Lower Coal Seam, Seam II or Main Coal Seam and Seam I or Upper Coal Seam, having average thicknesses of $7 \mathrm{~m}$, $25 \mathrm{~m}$ and $11 \mathrm{~m}$, respectively. The total thickness of the Pontian series is between 250 and $320 \mathrm{~m}$.
The basement of the Kostolac basin consists of Devonian crystalline rocks overlain by Neogene sediments (STOJANOVIĆ et al., 2012) (Fig. 3). The fresh water clastic coal-bearing series of the Kostolac basin is also of Upper Miocene (Pontian) age and hosts five coal seams, namely Seam III (the oldest and deepest) and Seams II-a, II, I-a and I. Only coal seams III, II and I are (or have been) explored in the Drmno, Ćirikovac and Klenovnik open pits. The average thickness of coal Seam III throughout the whole basin is $19.38 \mathrm{~m}$, while it is $1.43 \mathrm{~m}$ for IIa, $4.14 \mathrm{~m}$ for II, $1.53 \mathrm{~m}$ for Ia and $13.90 \mathrm{~m}$ for I coal seam (ŽIVOTIĆ et al., 2015).

\section{MATERIALS AND METHODS}

The ash sampling was carried out nearthe electric filter in the cooling phase, before it came into contact with water. For technological reasons, the slag was sampled in the wet state. The necessary quantity of samples for the ash laboratory tests were provided on two occasions, in May and June, and the slag laboratory tests were conducted in May. After the sample collection, the required amounts of material were separated for the following tests:

- physical examination of the ash and slag;

- chemical analyzes of the ash and slag;

- mineralogical tests of the ash and slag.

The humidity samples, density of solid particles, grain size composition and $\mathrm{pH}$ value tests were done to determine the physi- 


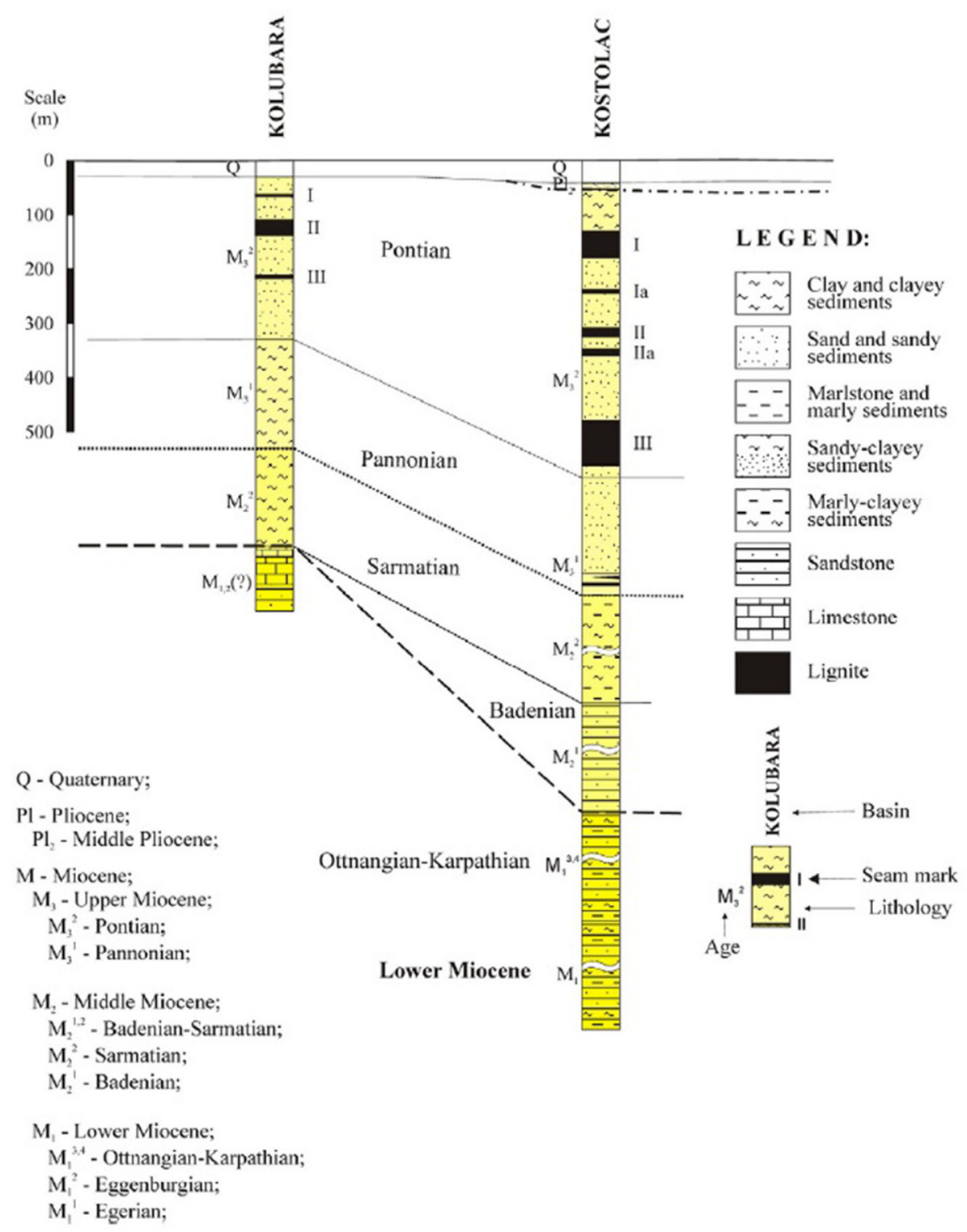

Figure 4. Lithostratigraphic cross section column of the Neogene from the Kolubara and Kostolac (ŽIVOTIĆ et al., 2015).

cal properties of the ash and slag. Sample humidity was examined according to the standard EN 1328-1, the solid particles volume weight test followed the standard EN 1097-7, grain size composition was tested according to EN 933-1, EN 451-2 and SRPS U. B1.018., and the $\mathrm{pH}$ value test was done according to SRPS $\mathrm{H}$. C8.209.

All the chemical tests on the fly ash and slag were done according to standards SRPS B.H8.359-369 and SRPS B.H8.327. Mineralogical sample properties of the fly ash and slag from PPNT A, PPNT B, PPKO A and PPKO B were determined by $\mathrm{X}$-ray examinations. X-ray diffraction is a non-destructive experimental method based on the diffraction of X-rays withcrystal lattice sized wavelengths. This method is primarily used for quality analysis, due to the fact that it enables the crystal components to be identified, the type of crystal lattice to be determined, as well as the presence of certain phases in the system, the deformation of the crystal lattice, and the size of crystals. It can also be used for quantity analysis, or more precisely, for an estimation of the proportions of the different components in the sample (ĐORĐEVIĆ, 2012). All samples were tested using the powder diffractometer PHILIPS PW 1710. The diffraction patterns (diagrams) were obtained with $\mathrm{CuK} \alpha$ radiation $\left(\lambda=1.54178 \times 10^{-10} \mathrm{~m}\right)$, created in the X-ray tube at $30 \mathrm{~mA}$ and a voltage of $40 \mathrm{kV}$. Sample recording was performed in the range of $2 \theta$ from 5 to $50^{\circ}$ with a step of $0.02^{\circ}$ and a retention time of $0.5 \mathrm{~s}$ at each step. The data position of the diffraction peaks $2 \theta\left(^{\circ}\right)$, the value of the flange distance $\mathrm{d}(\mathrm{m})$, and the corresponding intensities (I) use impulse unite (imp).

\section{RESULTS AND DISCUSSION}

The test results of the physical properties are shown in Table 1. The mean values, as well as the minimum and maximum values of ash and slag samples, are shown. For each power plant, six samples of fly ash in May were selected and one sample of slag. In June, three samples of fly ash were selected, with a total of 36 samples of fly ash and four slag samples (Table 1).

The chemcial composition results of the fly ash and slag from the thermal power plant (PP) samples tested are shown in Table 2.

Based on the analysis, the fly ash and slag from all four power plants have variable chemical composition. The chemical composition of samples consist mostly of silica $\left(\mathrm{SiO}_{2}\right)$, then alumina $\left(\mathrm{Al}_{2} \mathrm{O}_{3}\right)$, iron trioxide $\left(\mathrm{Fe}_{2} \mathrm{O}_{3}\right)$, calcium oxide $(\mathrm{CaO})$ and magnesium oxide $(\mathrm{MgO})$, while the chemical elements of sulfur trioxide $\left(\mathrm{SO}_{3}\right)$, sulfur $(\mathrm{S})$, sodium oxide $\left(\mathrm{Na}_{2} \mathrm{O}\right)$ and cal- 
Table 1. Physical properties of fly ash and slag.

\begin{tabular}{|c|c|c|c|c|c|c|c|}
\hline \multirow{2}{*}{ No. } & \multicolumn{2}{|c|}{ humidity of the sample (w) [\%] } & \multicolumn{2}{|c|}{ Fraction $<63 \mu \mathrm{m}(<63 \mu \mathrm{m})[\%]$} & \multicolumn{2}{|c|}{ Density $<2.9(<2.9)\left[\mathrm{g} / \mathrm{cm}^{3}\right]$} & \multirow{2}{*}{$\mathrm{pH}$ values } \\
\hline & Mena & Range & Mena & Range & Mena & Range & \\
\hline NT A - m & 0.43 & $0.30-0.57$ & 40.67 & $16.0-68.0$ & 2.11 & $2.05-2.15$ & 11.88 \\
\hline NT A - j & 0.29 & $0.22-0.38$ & 22.67 & $16.0-30.0$ & 2.09 & $2.08-2.10$ & 12.76 \\
\hline NT B - m & 0.26 & $0.08-0.71$ & 44.67 & $35.0-51.0$ & 2.13 & $2.08-2.20$ & 11.53 \\
\hline NT B -j & 0.20 & $0.15-0.28$ & 51.33 & $46.0-57.0$ & 2.10 & $2.05-2.16$ & 13.15 \\
\hline $\mathrm{KO} A-\mathrm{m}$ & 0.17 & $0.10-0.23$ & 17.33 & $15.0-19.0$ & 2.08 & $2.04-2.11$ & 11.02 \\
\hline $\mathrm{KOA}-\mathrm{j}$ & 0.41 & $0.37-0.47$ & 65.00 & $48.0-81.0$ & 2.13 & $2.02-2.33$ & 12.79 \\
\hline $\mathrm{KOB}-\mathrm{m}$ & 0.31 & $0.13-0.49$ & 18.00 & $10.0-25.0$ & 2.11 & $2.08-2.15$ & 11.30 \\
\hline $\mathrm{KOB}-\mathrm{j}$ & 0.27 & $0.23-0.30$ & 65.33 & $61.0-69.0$ & 2.32 & $2.30-2.34$ & 12.00 \\
\hline NT A (s) & 51.21 & - & 1.00 & - & 2.15 & - & 10.04 \\
\hline NT B (s) & 19.31 & - & 1.00 & - & 2.17 & - & 9.36 \\
\hline $\mathrm{KO} A(\mathrm{~s})$ & 28.56 & - & 2.00 & - & 2.04 & - & 7.77 \\
\hline $\mathrm{KO} B(\mathrm{~s})$ & 42.55 & - & 1.00 & - & 2.16 & - & 8.57 \\
\hline
\end{tabular}

$\mathrm{m}$ - fly ash for month May; $\mathrm{j}$ - fly ash for month June; (s) - slag; $\mathrm{w}$ - humidity of the sample; $<63 \mu \mathrm{m}$ - fraction of less than $63 \mu \mathrm{m} ;<2.9-\mathrm{density} \mathrm{of} \mathrm{less} \mathrm{than} 2.9 \mathrm{~g} / \mathrm{cm}^{3}$ $\mathrm{pH}$ - pH values; $\mathrm{NT}$ - Nikola Tesla; $\mathrm{KO}$ - Kostolac

Table 2. Results of chemical analyses of fly and slag taken from the power plants.

\begin{tabular}{|c|c|c|c|c|c|c|c|c|c|c|}
\hline \multirow{2}{*}{ No. } & LOI 1000 & $\mathrm{SiO}_{2}$ & $\mathrm{Al}_{2} \mathrm{O}_{3}$ & $\mathrm{Fe}_{2} \mathrm{O}_{3}$ & $\mathrm{CaO}$ & $\mathrm{MgO}$ & $\mathrm{SO}_{3}$ & $S$ & $\mathrm{Na}_{2} \mathrm{O}$ & $\mathrm{K}_{2} \mathrm{O}$ \\
\hline & \multicolumn{10}{|c|}{ mass (\%) } \\
\hline NT A - m & 6.43 & 51.64 & 21.87 & 5.54 & 1.05 & 3.01 & 0.85 & 0.33 & 0.57 & 1.05 \\
\hline NT A - j & 7.2 & 51.43 & 22.01 & 6.03 & 1.16 & 2.83 & 0.54 & 0.21 & 0.43 & 1.16 \\
\hline NT B - m & 2.58 & 55.38 & 22.57 & 5.46 & 8.30 & 2.87 & 0.45 & 0.18 & 0.45 & 1.12 \\
\hline NT B - j & 2.11 & 51.88 & 22.49 & 6.61 & 10.44 & 3.28 & 0.66 & 0.26 & 0.58 & 1.23 \\
\hline $\mathrm{KO} A-\mathrm{m}$ & 2.21 & 51.96 & 23.22 & 9.82 & 7.80 & 2.62 & 0.33 & 0.13 & 0.44 & 0.77 \\
\hline$K O A-j$ & 4.18 & 44.55 & 20.80 & 11.23 & 11.71 & 2.73 & 2.45 & 0.98 & 0.50 & 0.69 \\
\hline $\mathrm{KO} B-\mathrm{m}$ & 3.37 & 51.41 & 22.13 & 9.98 & 8.05 & 2.50 & 0.53 & 0.21 & 0.48 & 0.76 \\
\hline$K O B-j$ & 1.98 & 46.04 & 21.67 & 11.44 & 11.10 & 2.64 & 2.27 & 0.88 & 0.51 & 0.67 \\
\hline NT A (s) & 9.88 & 51.06 & 20.50 & 6.14 & 7.27 & 2.70 & 0.12 & 0.05 & 0.53 & 1.23 \\
\hline NT B (s) & 10.5 & 52.12 & 20.97 & 6.30 & 5.51 & 2.30 & 0.16 & 0.06 & 0.51 & 1.02 \\
\hline $\mathrm{KO} A(\mathrm{~s})$ & 36.02 & 32.98 & 12.24 & 7.56 & 5.53 & 1.83 & 1.96 & 0.78 & 0.48 & 0.69 \\
\hline $\mathrm{KO} B(\mathrm{~s})$ & 4.47 & 48.91 & 21.54 & 11.32 & 8.87 & 2.43 & 0.23 & 0.40 & 0.49 & 0.74 \\
\hline
\end{tabular}

LOI 1000 - loss on ignition $1000^{\circ} \mathrm{C}$; $\mathrm{m}$ - fly ash for month May; $\mathrm{j}$ - fly ash for month June; (s) - slag; NT - Nikola Tesla; KO - Kostolac

cium oxide $(\mathrm{CaO})$ are only present in very small quantities. The main reason for the variability of the chemical composition is the waste-rock presence of inorganic composition. Based on the chemical composition the module $\mathrm{R}$ is determined, and is shown in Fig. 5. The R module is used for determination of ash and slag classification according to the chemical composition.
The formula for determining the $\mathrm{R}$ module is:

$$
R=\frac{\left(\mathrm{SiO}_{2}+\mathrm{AlO}_{3}\right)}{\left(\mathrm{CaO}+\mathrm{MgO}+\mathrm{Fe}_{2} \mathrm{O}_{3}\right)}
$$

According to the size of the module $\mathrm{R}$, the fly ash can be classified as silica-calcium $(\mathrm{R}<2)$, silicate $(\mathrm{R}=2-6)$ or aluminumsilicate $(\mathrm{R}>6)$.

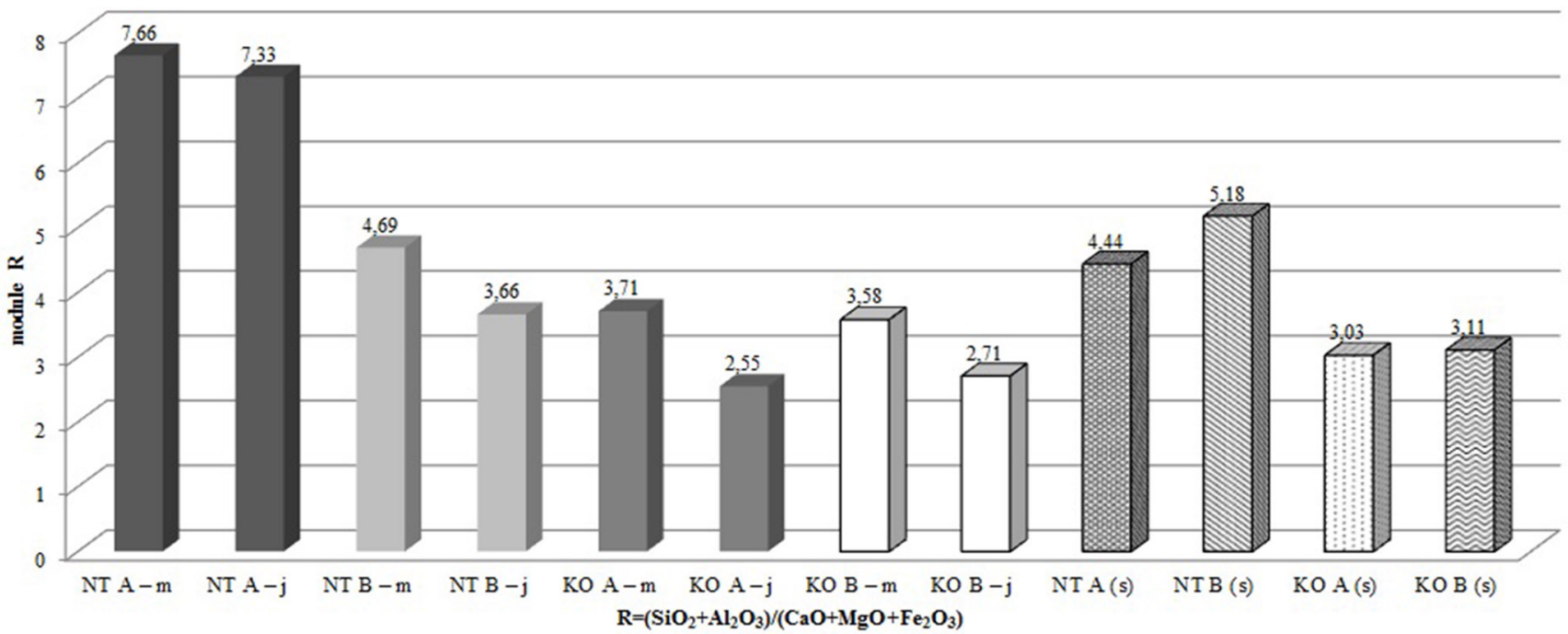

Figure 5. The R module according to PP ( $m$ - fly ash for month May; - fly ash for month June; (s) - slag; NT - Nikola Tesla; KO - Kostolac). 
Table 3. The percentage composition by mass of minerals in the samples of the fly ash and slag.

\begin{tabular}{|c|c|c|c|c|c|c|c|c|c|c|}
\hline \multirow{2}{*}{ No. } & the amorphous material & Q & $f$ & $M$ & $\mathrm{Ml}$ & $A n$ & $\mathrm{Cr}$ & $\mathrm{He}$ & $\mathrm{CaO}$ & Total \\
\hline & \multicolumn{10}{|c|}{ mass (\%) } \\
\hline NT A-m & 58 & 16 & 10 & 5 & 5 & 3 & 3 & - & - & 100 \\
\hline NT A - j & 66 & 17 & 9 & 3 & 2 & 2 & - & - & - & 99 \\
\hline NT B - m & 50 & 17 & 12 & 6 & 4 & 7 & 4 & - & - & 100 \\
\hline NT B - j & 50 & 10 & 14 & 8 & 6 & 7 & 3 & - & 2 & 100 \\
\hline $\mathrm{KO} A-\mathrm{m}$ & 55 & 7 & 23 & 7 & - & - & 4 & 4 & - & 100 \\
\hline $\mathrm{KO} A-\mathrm{j}$ & 55 & 10 & 12 & 3 & 2 & 10 & 1 & 7 & - & 100 \\
\hline $\mathrm{KOB}-\mathrm{j}$ & 50 & 6 & 15 & 2 & 2 & 10 & 5 & 10 & - & 100 \\
\hline NT A (s) & 56 & 21 & 11 & 3 & - & - & 4 & - & 5 & 100 \\
\hline NT B (s) & 58 & 31 & 5 & 3 & - & - & 3 & - & - & 100 \\
\hline $\mathrm{KO} A(\mathrm{~s})$ & 63 & 26 & 8 & - & - & - & - & - & 3 & 100 \\
\hline $\mathrm{KOB}(\mathrm{s})$ & 45 & 5 & 25 & 10 & 2 & - & 10 & 3 & - & 100 \\
\hline
\end{tabular}

$\mathrm{m}$ - fly ash for month May; $\mathrm{j}$ - fly ash for month June; (s) - slag; AM - the amorphous material; $\mathrm{Q}$ - quartz; $\mathrm{f}$ - feldspar; $\mathrm{M}$ - mullite; $\mathrm{Ml}$ - melilite; $\mathrm{An}$ - anhydrite; $\mathrm{Cr}$ - cristobalite; $\mathrm{He}$ - hematite; $\mathrm{CaO}$ - calcite; NT - Nikola Tesla; KO - Kostolac

According to this classification, fly ash from PPNT A for May and June belongs to the aluminum-silicate group, and slag belongs to a silicate group, because the module is in the range of 2 to 6. Fly ash from PPNT B, PPKO A and PPKO B belongs to a silicate group, and slag from all three of these power plants also belongs to a silicate group.

Percentage compositionof minerals in the samples of the fly ash and slag are shown in Table 3.

Comparing the results of test samples (Table 3) by the X-ray diffraction method it can be observed that:

- all samples of ash contain a significant amount of amorphous material (AM);

- samples of ash from Obrenovac include quartz (Q) and feldspar (f) as the most common minerals, while the other identified minerals are represented in subordinate amounts.
Samples of ash from Kostolac contain significantly higher amounts of haematite (He) and anhydrite (An);

- samples of slag from Obrenovac are similar to each other compared to the samples of slag from Kostolac which show a greater difference with each other.

5.1. Relationships between physical, chemical and mineral composition

The reserach studied the dependence between the physical, chemical and mineral compositionafter which certain correlation coefficients were determined and compared between the ash and slag. Dependence for all the samples was done using polynomial functions, because only this function gave the best correlation results. Results of the correlation coefficient, as a relationship and a correlation sign, are shown in Table 4. Based on analysis of the

Table 4. Correlation between physical, chemical and mineral composition of fly ash and slag used from the power plants.

\begin{tabular}{|c|c|c|}
\hline \multirow{2}{*}{ Symbol } & \multicolumn{2}{|c|}{ Significant correlation coefficient values with: } \\
\hline & fly ash & slag \\
\hline \multicolumn{3}{|c|}{ chemical composition } \\
\hline LOI & $\mathrm{SiO}_{2}(0.24) \mathrm{Al}_{2} \mathrm{O}_{3}(0.46) \mathrm{Cr}(0.72)$ & $\mathrm{SiO}_{2}(0.99) \mathrm{Al}_{2} \mathrm{O}_{3}(0.99) \mathrm{Cr}(0.99)$ \\
\hline $\mathrm{SiO}_{2}$ & $\begin{array}{l}\mathbf{Q}(\mathbf{0 . 5 3}) \mathbf{K}_{\mathbf{2}} \mathbf{O}(\mathbf{0 . 8 3}) \mathrm{CaO}(0.85) \mathrm{SO}_{3}(0.93) \mathbf{M g O}(0.97) \mathrm{He}(0.82) \mathbf{R}(0.48) w(0.42) \\
\mathbf{A M}(\mathbf{0 . 2 1})\end{array}$ & $\begin{array}{l}Q(0.31) \mathbf{K}_{\mathbf{2}} \mathrm{O}(\mathbf{0 . 8 3}) \mathrm{CaO}(\mathbf{0 . 4 8}) \mathrm{SO}_{3}(0.99) \mathrm{MgO}(0.30) \mathrm{He}(0.20) \mathrm{R}(0.74) \mathrm{w}(0.75) \\
A M(0.97)\end{array}$ \\
\hline $\mathrm{Al}_{2} \mathrm{O}_{3}$ & $\begin{array}{l}\mathrm{SO}_{3}(0.86) \mathrm{CaO}(0.83) \mathrm{Fe}_{2} \mathrm{O}_{3}(0.71) \mathbf{M g O}(0.29) \mathbf{M}(0.76) \mathrm{Ml}(0.59) \mathrm{He}(0.49) \mathbf{R}(0.84) \\
w(0.83)<2.9(0.64) \mathrm{AM}(0.18)\end{array}$ & $\begin{array}{l}\mathrm{SO}_{3}(0,99) \mathrm{CaO}(0.58) \mathrm{Fe}_{2} \mathrm{O}_{3}(0.98) \mathrm{MgO}(0.99) \mathrm{M}(0.99) \mathrm{Ml}(0.41) \mathrm{He}(0.41) \mathrm{R}(0.57) \\
\mathrm{w}(0.61)<2.9(0.99) A M(0.97)\end{array}$ \\
\hline $\mathrm{Fe}_{2} \mathrm{O}_{3}$ & $Q(0.74) \mathrm{SiO}_{2}(0.76) \mathrm{Al}_{2} \mathrm{O}_{3}(0.60) \mathrm{R}(0.90)$ & $\mathrm{Q}(0.95) \mathrm{SiO}_{2}(0.92) \mathbf{A l}_{2} \mathbf{O}_{3}(\mathbf{0 . 9 2}) R(0.73)$ \\
\hline $\mathrm{CaO}$ & $\begin{array}{l}\mathbf{S O}_{3}(\mathbf{0 . 6 6}) \mathrm{MgO}(0.47) \mathrm{SiO}_{2}(0.59) Q(0.59) \mathrm{K}_{2} \mathrm{O}(0.79) \mathrm{Al}_{2} \mathrm{O}_{3}(0.45) \mathbf{N a}_{\mathbf{2}} \mathbf{O}(\mathbf{0 . 6 0}) R(0.97) \\
w(0.30)<\mathbf{2 . 9}(\mathbf{0 . 4 8}) A M(0.80)\end{array}$ & $\begin{array}{l}\mathrm{SO}_{3}(0.73) \mathbf{M g O}(\mathbf{0 . 6 1}) \mathbf{S i O}_{\mathbf{2}}(\mathbf{0 . 9 9}) Q(0.96) K_{2} \mathrm{O}(0.24) \mathbf{A l}_{\mathbf{2}} \mathbf{O}_{\mathbf{3}}(\mathbf{0 . 7 0}) \mathrm{Na}_{\mathbf{2}} \mathbf{O}(\mathbf{0 . 0 7}) \\
R(0.59) \mathbf{w}(\mathbf{0 . 8 0})<\mathbf{2 . 9}(\mathbf{0 . 7 1}) A M(0.93)\end{array}$ \\
\hline $\mathrm{SO}_{3}$ & $\mathrm{CaO}(0.91) \mathrm{MgO}(0.26) \mathrm{SiO}_{2}(0.96) \mathrm{Al}_{2} \mathrm{O}_{3}(0.86) \mathrm{Q}(0.52)$ & $\mathrm{CaO}(0.56) \mathrm{MgO}(0.99) \mathrm{SiO}_{2}(0.99) \mathrm{Al}_{2} \mathrm{O}_{3}(1.00) \mathbf{Q}(\mathbf{0 . 3 6})$ \\
\hline $\mathrm{MgO}$ & $\mathrm{CaO}(0.34) \mathrm{SO}_{3}(0.59) \mathbf{S i O}_{\mathbf{2}}(\mathbf{0 . 3 0}) \mathbf{A l}_{\mathbf{2}} \mathbf{O}_{\mathbf{3}}(\mathbf{0 . 2 8}) \mathbf{R}(\mathbf{0 . 3 7})$ & $\mathrm{CaO}(0.84) \mathrm{SO}_{3}(0.92) \mathrm{SiO}_{2}(0.89) \mathrm{Al}_{2} \mathrm{O}_{3}(0.93) \mathrm{R}(0.82)$ \\
\hline $\mathrm{Na}_{2} \mathrm{O}$ & $\mathrm{CaO}(0.47) \mathrm{He}(0.34) \mathrm{pH}(0.43) f(0.49)$ & $\mathrm{CaO}(\mathbf{0 . 8 2}) \mathrm{He}(0.38) \mathbf{p H}(0.99) f(0.45)$ \\
\hline $\mathrm{K}_{2} \mathrm{O}$ & $\mathbf{Q}(\mathbf{0 . 6 9}) \mathbf{S i O}_{\mathbf{2}}(\mathbf{0 . 6 8}) \mathrm{CaO}(0.49) \mathrm{He}(0.90) \mathbf{R}(\mathbf{0 . 7 7}) w(0.16)<2.9(0.47) \mathbf{A M}(\mathbf{0 . 5 7})$ & $\mathbf{Q}(\mathbf{0 . 4 8}) \mathrm{SiO}_{\mathbf{2}}(\mathbf{0 . 8 2}) \mathrm{CaO}(0.84) \mathrm{He}(0.53) \mathbf{R}(0.99) \mathbf{w}(0.99)<2.9(0.68) \mathrm{AM}(0.98)$ \\
\hline $\mathrm{R}$ & $\begin{array}{l}\mathrm{He}(0.75) \mathbf{S i O}_{\mathbf{2}}(\mathbf{0 . 5 6}) \mathbf{A l}_{\mathbf{2}} \mathbf{O}_{\mathbf{3}}(\mathbf{0 . 5 0}) \mathbf{K}_{\mathbf{2}} \mathbf{O}(\mathbf{0 . 8 4}) \mathbf{A M}(\mathbf{0 . 7 2}) \mathbf{w}(\mathbf{0 . 3 1}) \mathrm{Fe}_{2} \mathrm{O}_{3}(0.79) \\
<2.9(0.42) \mathbf{M g O} \mathbf{0}(\mathbf{0 . 6 1}) \mathbf{p H}(\mathbf{0 . 3 2}) \mathrm{CaO}(0.98) \mathbf{Q}(\mathbf{0 . 6 4}) \mathrm{Cr}(0.43)\end{array}$ & $\begin{array}{l}\mathrm{He}(0.53) \mathbf{S i O}_{\mathbf{2}}(\mathbf{0 . 9 9}) \mathbf{A l}_{\mathbf{2}} \mathbf{O}_{\mathbf{3}}(\mathbf{0 . 8 1}) \mathbf{K}_{\mathbf{2}} \mathbf{O}(\mathbf{0 . 9 8}) \mathbf{A M}(\mathbf{0 . 9 2}) w(0.99) \mathrm{Fe}_{2} \mathrm{O}_{3}(0.92) \\
<\mathbf{2 . 9 ( 0 . 6 6 )} \mathbf{M g O}(\mathbf{0 . 5 2}) \mathbf{p H}(\mathbf{0 . 8 1}) \mathrm{CaO}(0.54) \mathbf{Q}(\mathbf{0 . 6 3}) \mathrm{Cr}(0.93)\end{array}$ \\
\hline \multicolumn{3}{|c|}{ mineral composition } \\
\hline AM & $\begin{array}{l}\mathrm{SiO}_{2}(0.40) \mathbf{K}_{\mathbf{2}} \mathbf{O}(\mathbf{0 . 4 0}) \mathrm{Al}_{2} \mathrm{O}_{3}(0.18) \mathrm{CaO}(0.82) \mathrm{Cr}(0.78) \mathrm{He}(0.36) \mathrm{MI}(0.24)<63(0.53) \\
\mathbf{R}(\mathbf{0 . 7 6})\end{array}$ & $\begin{array}{l}\mathrm{SiO}_{2}(0.98) \mathbf{K}_{\mathbf{2}} \mathbf{O}(\mathbf{0 . 1 6}) \mathrm{Al}_{2} \mathrm{O}_{3}(0.91) \mathrm{CaO}(0.96) \mathrm{Cr}(0.99) \mathrm{He}(0.92) \mathrm{MI}(0.92)<\mathbf{6 3}(\mathbf{0 . 6 6}) \\
\mathbf{R}(\mathbf{0 . 2 8})\end{array}$ \\
\hline Q & $\mathrm{SiO}_{\mathbf{2}}(\mathbf{0 . 5 3}) \mathbf{K}_{\mathbf{2}} \mathbf{O}(\mathbf{0 . 7 0}) \mathrm{CaO}(0.65) \mathrm{SO}_{3}(0.58) \mathrm{Fe}_{2} \mathrm{O}_{3}(0.58) \mathbf{M I}(0.09)<63(0.67) \mathbf{R}(\mathbf{0 . 6 7 )}$ & $\mathrm{SiO}_{2}(0.99) \mathbf{K}_{\mathbf{2}} \mathbf{O}(\mathbf{0 . 4 1}) \mathrm{CaO}(0.98) \mathbf{S O}_{3}(\mathbf{0 . 7 5}) \mathrm{Fe}_{2} \mathrm{O}_{3}(0.94) \mathrm{MI}(0.93)<63(0.31) \mathbf{R}(\mathbf{0 . 6 6})$ \\
\hline$f$ & $\mathrm{Na}_{2} \mathrm{O}(0.21)$ & $\mathrm{Na}_{2} \mathrm{O}(0.27)$ \\
\hline M & $\mathbf{A l}_{2} \mathbf{O}_{3}(\mathbf{0 . 7 8})<2.9(0.61)<63(0.59)$ & $\mathrm{Al}_{2} \mathrm{O}_{3}(0.94)<2.9(0.63)<63(0.63)$ \\
\hline $\mathrm{Ml}$ & $\mathbf{p H}(0.56) \mathbf{Q}(0.69) A M(0.40) \mathrm{Al}_{2} \mathrm{O}_{3}(0.37) \mathrm{Fe}_{2} \mathrm{O}_{3}(0.74)$ & $p H(0.68) Q(0.99) A M(0.99) \mathbf{A l}_{\mathbf{2}} \mathbf{O}_{3}(\mathbf{0 . 9 2}) \mathbf{F e}_{\mathbf{2}} \mathbf{O}_{3}(\mathbf{0 . 9 9})$ \\
\hline $\mathrm{Cr}$ & $L O I(0.71) A M(0.73) p H(0.69) R(0.56)$ & $L O I(0.99) A M(0.99) \mathbf{p H}(\mathbf{0 . 6 8}) R(0.26)$ \\
\hline $\mathrm{He}$ & $\begin{array}{l}\mathbf{F e}_{2} \mathbf{O}_{3}(\mathbf{0 . 9 8}) \mathbf{w}(\mathbf{0 . 1 0}) \mathrm{Na}_{2} \mathrm{O}(0.80) A M(0.37) \mathrm{K}_{2} \mathrm{O}(0.96) \mathrm{SiO}_{2}(0.82) \mathrm{Al}_{2} \mathrm{O}_{3}(0.89) p H(0.24) \\
R(0.90)\end{array}$ & $\begin{array}{l}\mathbf{F e}_{\mathbf{2}} \mathbf{O}_{\mathbf{3}}(\mathbf{0 . 9 9}) \mathbf{w}(\mathbf{0 . 6 5}) \mathrm{Na}_{2} \mathrm{O}(0.50) A M(0.99) \mathrm{K}_{2} \mathrm{O}(0.48) \mathbf{S i O}_{\mathbf{2}}(\mathbf{0 . 9 4}) \mathbf{A l}_{\mathbf{2}} \mathbf{O}_{\mathbf{3}}(\mathbf{0 . 9 2}) \\
\mathrm{pH}(0.68) R(0.53)\end{array}$ \\
\hline \multicolumn{3}{|c|}{ physical composition } \\
\hline $\mathrm{pH}$ & $\mathrm{Na}_{2} \mathrm{O}(0.47) \mathrm{Fe}_{2} \mathrm{O}_{3}(0.24) \mathrm{Kr}(0.70) \mathrm{He}(0.41) \mathbf{M I}(\mathbf{0 . 5 8}) \mathbf{R}(\mathbf{0 . 4 0})$ & $\mathrm{Na}_{\mathbf{2}} \mathrm{O}(\mathbf{0 . 9 9}) \mathrm{Fe}_{2} \mathrm{O}_{3}(0.99) \mathbf{K r}(\mathbf{0 . 9 9}) \mathrm{He}(0.25) \mathrm{Ml}(0.25) \mathbf{R}(\mathbf{0 . 9 7})$ \\
\hline w & $\mathrm{CaO}(0.65) \mathrm{K}_{2} \mathrm{O}(0.33) \mathrm{Al}_{2} \mathrm{O}_{3}(0.80) \mathrm{SiO}_{2}(0.44) \mathbf{H e}(\mathbf{0 . 0 8}) \mathbf{R}(\mathbf{0 . 7 4})$ & $\mathrm{CaO}(0.97) \mathrm{K}_{\mathbf{2}} \mathrm{O}(0.78) \mathbf{A l}_{\mathbf{2}} \mathbf{O}_{\mathbf{3}}(0.36) \mathrm{SiO}_{\mathbf{2}}(\mathbf{0 . 6 5}) \mathrm{He}(0.34) R(0.96)$ \\
\hline$<2.9$ & $\mathbf{w}(0.39) \mathrm{CaO}(\mathbf{0 . 5 5}) \mathrm{K}_{2} \mathrm{O}(0.63) \mathrm{Al}_{2} \mathrm{O}_{3}(0.43) \mathrm{M}(0.75) \mathrm{R}(0.58)$ & $w(0.63) \mathrm{CaO}(0.47) \mathrm{K}_{2} \mathrm{O}(0.77) \mathrm{Al}_{2} \mathrm{O}_{3}(0.99) \mathrm{M}(0.99) \mathrm{R}(0.63)$ \\
\hline$<63$ & $\mathrm{M}(0.60) \mathrm{AM}(0.56) \mathrm{Q}(0.59)$ & $M(1.00) \mathrm{AM}(0.98) \mathrm{Q}(\mathbf{0 . 4 1 )}$ \\
\hline
\end{tabular}

LOI 1000 - loss on ignition $1000^{\circ} \mathrm{C} ; \mathrm{R}$ - module $\mathrm{R} ; \mathrm{AM}$ - the amorphous material; $\mathrm{Q}$ - quartz; $\mathrm{f}$ - feldspar; $\mathrm{M}$ - mullite; $\mathrm{Ml}$ - melilite; $\mathrm{Cr}$ - cristobalite; He - hematite; $\mathrm{pH}-\mathrm{pH}$ values; $\mathrm{w}$ - humidity of the sample; $<2.9$ - density of less than $2.9 \mathrm{~g} / \mathrm{cm}^{3} ;<63 \mu \mathrm{m}$ - fraction of less than $63 \mu \mathrm{m}$ 

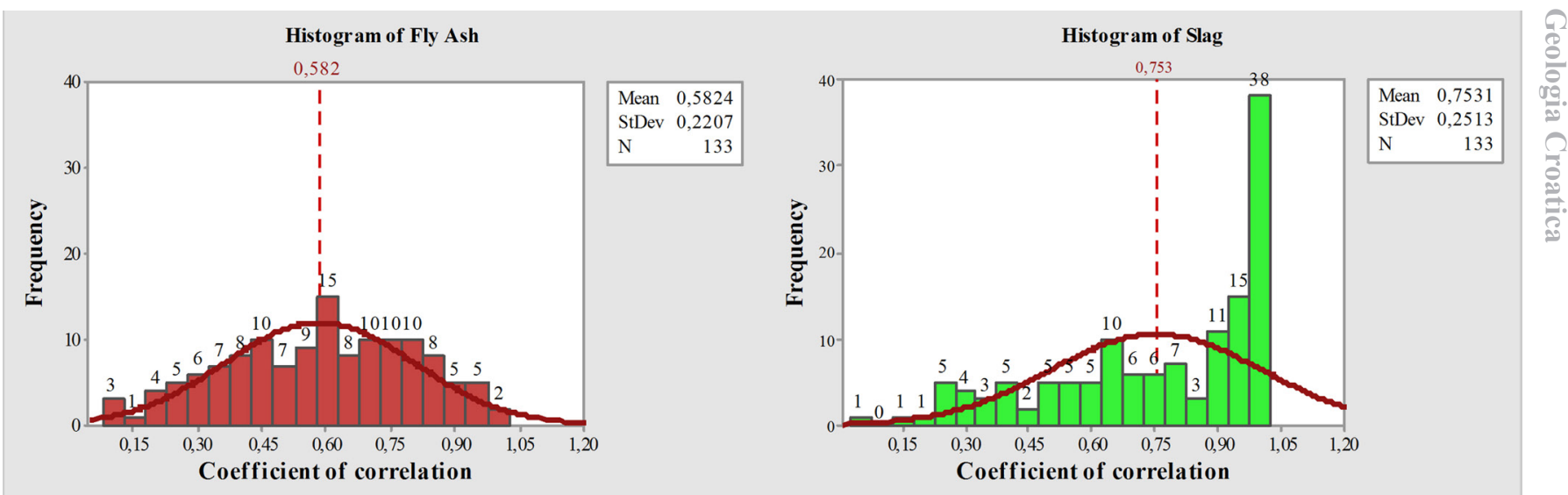

Figure 6. Histogram of fly ash and slag results (StDev - Standard Deviation; N-number of samples).

results, a total of 266 correlations were made (133 for fly ash and 133 for slag), wherein the positive correlations are shown in bold and negative correlations are italic. Positive and negative correlation coefficients for all the tested dependencies are equally represented. During the analysis of the results, absolute values of the correlation coefficients are observed in order to achieve easier comparative analysis of the test samples. A significantly large number of dependencies has been achieved with chemical properties, and then with mineral and finally with physical properties.

The research results are compared with each other and shown in the histogram (Fig. 6), from which the frequency of correlation coefficients, the mean value of the analyzed results, standard deviation and the number of tested samples can be observed.

From the histogram for fly ash, it can be seen that in the range of 0.20 to 0.90 there is approximately an equal number of correlation coefficients except for the coefficient of 0.60 , where there is a higher amount of correlation coefficients. The histogram of slag results shows a small representation of the correlation coefficients untill 0.60 , then small jumps appear with approximate values, while a large dispersion of correlation coefficients is observed from 0.9 to 1.0 .

\section{CONCLUSION}

Based on the obtained research results it is evident that the sepower plants use two different coal basins, ie. a different type of combustion coal, and based on that different values of the chemical, mineral and physical compositions are obtained. From the entire study the following conclusions can be drawn:

- fly ash and slag have variable chemical, mineralogical and physical properties, and depend on the natural composition and quality of coal for each specific coal basin,

- dependencies between the chemical, mineral and physical properties make a good basis for predicting and solvingspecific technological and ecological problems related to the use of ash and slag,

- using different types of coal from Kolubara and Kostolac basins, fairly good correlation coefficients for test samples of fly ash and slag were obtained,

- from the analyzed dependencies and presented results of the correlation coefficients, it can be concluded that slag has much better values between the achieved dependencies (physical properties, chemical and mineral composition), except for the case of $\mathrm{SiO}_{2}$ where it is noticeable that fly ash has a higher values of the correlation coefficients.

\section{REFERENCES}

ĐORĐEVIĆ, M. (2012): Geohemijska analiza tragova metala Riblje gline s lokaliteta Kirkevig (Stevns Klint, Danska) [Geochemical analysis of trace metals of Fish Clay from locality Kirkevig (Stevns Klint, Denmark) - in Serbian, with an English Abstract].- Unpubl. PhD Thesis, Faculty of Sciences, University of Niš, 38 p.

EN 451-2 (1994): Method of testing fly ash - Part 2: Determination of fineness by wet sieving.

EN 933-1 (1997): Tests for geometrical properties of aggregates - Part 1: Determination of particle size distribution - Sieving method.

EN 1097-7 (1999): Tests for mechanical and physical properties of aggregates - Part 7: Determination of the particle density of filler - Pyknometer metod.

EN 1328-1 (2003): Unbound and hydraulically bound mixtures - Part 1: Test methods for laboratory reference density and water content - Introduction, general requirements and sampling.

KEZOVIĆ, M. (2011): Coal bearing in Kolubara Basin.- The Journal of the Public Enterprise Electric Power Industry of Serbia, 64, 154-163. (in Serbian with English abstract)

KIM, B., PREZZI, M. \& SALGADO, R. (2005): Geotechnical Properties of Fly and Bottom Ash Mixtures for Use in Highway Embankments.- Journal of Geotechnical and Geoenvironmental Engineering, 131/7, 914-924

MILETIĆ, S. \& ILIĆ M. (2007): Korišćenje elektrofilterskog pepela u građenju i građevinskim materijalima.- Association of Civil Engineers and Technicians of Serbia, Belgrade.

SRPS B.H8.359 (1973): Methods of analysis of coal and coke - Determination of chemical composition of fuel ash - General requirements.

SRPS B.H8.360 (1973): Methods of analysis of coal and coke - Determination of silica $\left(\mathrm{SiO}_{2}\right)$ in ash from solid fuels.

SRPS B.H8.361 (1973): Methods of analysis of coal and coke-Determination of barium oxide $(\mathrm{BaO})$ in ash from solid fuels.

SRPS B.H8.362 (1973): Methods of analysis of coal and coke - Determination of ferric oxide $\left(\mathrm{Fe}_{2} \mathrm{O}_{3}\right)$ in ash from solid fuels.

SRPS B.H8.363 (1973): Methods of analysis of coal and coke - Determination of titanium oxide $\left(\mathrm{TiO}_{2}\right)$ in ash from solid fuels.

SRPS B.H8.364 (1973): Methods of analysis of coal and coke- Determination of aluminum oxide $\left(\mathrm{Al}_{2} \mathrm{O}_{3}\right)$ in ash from solid fuels.

SRPS B.H8.365 (1973): Methods of analysis of coal and coke - Determination of calcium oxide $(\mathrm{CaO})$ in ash from solid fuels.

SRPS B.H8.366 (1973): Methods of analysis of coal and coke - Determination of magnesium oxide $(\mathrm{MgO})$ in ash from solid fuels.

SRPS B.H8.367 (1973): Methods of analysis of coal and coke - Determination of manganese oxide $\left(\mathrm{Mn}_{3} \mathrm{O}_{4}\right)$ in ash from fuels.

SRPS B.H8.368 (1973): Methods of analysis of coal and coke - Determination of sodium and potassium oxide $\left(\mathrm{Na}_{2} \mathrm{O}_{2}\right.$ and $\left.\mathrm{K}_{2} \mathrm{O}\right)$ in ash from solid fuels.

SRPS B.H8.369 (1973): Methods of analysis of coal and coke - Determination of sulfur trioxide $\left(\mathrm{SO}_{3}\right)$ in ash from solid fuels.

SRPS B.H8.327 (1989): Solid mineral fuels - Determination of phosphorus content Reduced molybdophosphate photometric method.

SRPS U.B1.018 (2005): Testig soils - Determination of particle size distribution.

SPRS H.C8.209 (1989): Pigments and extenders - Determination of $\mathrm{pH}$ - value of an aqueous suspension.

STOJANOVIĆ, K., ŽIVOTIĆ, D., ŠAJNOVIĆ, A., CVETKOVIĆ, O., NYTOFT, H.P. \& SCHEEDER, G. (2012): Drmno lignite field (Kostolac Basin, Serbia): origin and palaeoenvironmental implications from petrological and organic geochemical studies.- Journal of the Serbian Chemical Society, 77/8, 1109-1127. 
THOMAS, M. (2007): Optimizing the Use of Fly Ash in Concrete, Portland Cement Association, $1-24$.

VASSILEV, S., BAXTER, D., ANDERSON, L. \& VASSILEV, C. (2013): An overview of the composition and application of biomass ash. Part 1. Phase-mineral and chemical composition and classification.- Fuel, 105, 40-76.

VASSILEV, S., BAXTER, D. \& VASSILEV, C. (2014): An overview of the behaviour of biomass during combustion: Part II. Ash fusion and ash formation mechanisms of biomass types.- Fuel, 117, 152-183.

VASSILEV, S., MENENDEZ, R., ALVAREZ, D., DIAZ-SOMOANO, M. \& MARTINEZ-TARAZONA, R. (2003): Phase-mineral and chemical composition of coal fly ashes as a basis for their multicomponent utilization. 1. Characterization of feed coals and fly ashes.- Fuel, 82, 1793-1811.

VASSILEV, S., MENENDEZ, R., ALVAREZ, D., DIAZ-SOMOANO, M. \& MARTINEZ-TARAZONA, R. (2004a): Phase-mineral and chemical composition of coal fly ashes as a basis for their multicomponent utilization. 2. Characterization of ceramic cenosphere and salt concentrates.-Fuel, 83, 585-603.

VASSILEV, S., MENENDEZ, R., BORREGO, A., DIAZ-SOMOANO, M. \& MARTINEZ-TARAZONA, R. (2004b): Phase-mineral and chemical composition of coal fly ashes as a basis for their multicomponent utilization. 3. Characterization of magnetic and char concentrates.- Fuel, 83, 1563-1583.
VASSILEV, S. \& MENENDEZ, R. (2005): Phase-mineral and chemical composition of coal fly ashes as a basis for their multicomponent utilization. 4. Characterization of heavy concentrates and improved fly ash residues.- Fuel, 84, 973-991.

VASSILEV, S. \& VASSILEVA, C. (2007): A new approach for the classification of coal fly ashes based on their origin, composition, properties, and behavior.- Fuel, 86, 1490-1512.

WARD, C. \& FRENCH, D. (2005): Relation between Coal and Fly Ash Mineralogy, Based on Quantitative X-Ray Diffraction Methodos. 2005 World of Coal Ash, International Symposium, April 11-15, 2005, 1-14.

ŽIVOTIĆ, D., BECHTEL, A., SACHSENHOFER, R., GRATZER, R., RADIĆ, D., OBRADOVIĆ, M. \& STOJANOVIĆ, K. (2015): Reprint of „Petrological and organic geochemical properties of lignite from the Kolubara and Kostolac basins, Serbia: Implication on Grindability Index".- International Journal of Coal Geology, 157, 165-183.

ŽIVOTIĆ, D., STOJANOVIĆ, K., GRŽETIĆ, I., JOVANČIĆEVIĆ, B., CVETKOVIĆ, O., ŠAJNOVIĆ, A., SIMIĆ, V., STOJAKOVIĆ, R. \& SCHEEDER, G. (2013): Petrological and geochemical composition of lignite from the D field, Kolubara basin (Serbia).- International Journal of Coal Geology, 111, 5-22. 